\title{
Rethinking Comparativism
}

\author{
Gayatri Chakravorty Spivak
}

\section{W}

HAT IS IT THAT ONE "compare"-s in Comparative Literature? Goethe's Weltiteratur is usually invoked when talking about the beginnings of a comparative literature. The other story is Leo Spitzer and Erich Auerbach in Turkey. There is also the story of the rise of the discipline of Comparative Literature to intellectual prominence in the United States in the period following the Second World War, largely as a result of the migration to the United States of a group of noted European comparativists seeking asylum from totalitarianism. This group had a great influence in fostering the theoretical transformation of literary studies and in bringing about fundamental changes in national literature studies. But to think of comparative literature as comparative had something to do with the notion of la littérature comparée in France-where comparison implicitly referred to the standards of the French eighteenth century. This attitude is reflected in the fundamental premises of Pascale Casanova's work today. ${ }^{1}$ René Etiemble's Comparaison n'est pas raison attempted, in 1963, to combat that impulse in a manner that is still favorably comparable to much that goes on in the Euro-U.S. today. ${ }^{2}$ But in terms of the questions we are asking, it is still too much within the internationalist side of cold war logic-going no further than the front-line languages of India and East Asia, with a somewhat paternalistic approach. Whatever the outcome of that debate, and whatever the status of the classical traditions of Asia, Comparative Literature within the United States remained confined to European literary regionalism. After the cold war, the division between a Eurocentric Comparative Literature and geopolitically oriented "Area Studies" seemed to have become less tenable than before. But comparison in favor of the European tradition has remained in place.

Seen another way, comparison assumes a level playing field and the field is never level, if only in terms of the interest implicit in the perspective. It is, in other words, never a question of compare and contrast, but rather a matter of judging and choosing. When the playing fields are not even continuous, the problem becomes immense. Most metropolitan countries acknowledge the problem simply because of the volume of migration in recent decades. There, a certain degree of levelness 
(entry into the circuit of citizenship, desired when denied) is already established. I, on the other hand, write as I have always written, as soon as I began to publish in the seventies, with a sense of the world rather than the demands of immigrants, in themselves also and of course a powerful disciplinary initiative. I would, however, like to distinguish my position, simply because it does not arise from "the forcing of cultures into greater proximity." Charles Bernheimer wanted Comparative Literature to include "subaltern perspectives." ${ }^{\prime 3}$ As I have regularly noted, I am just as regularly asked to help curate shows that will, give or take the culture, "bring the barrio to the museum." This is to misunderstand even the way in which denial/desire/demand work in the establishment of the class-cross-hatched space of migrant generations in metropolitan space. The degree of systemic change necessary for such transference to take place is precisely the issue.

It is absurd to expect a humanities discipline to bring about these changes. The result of the steady influx of people from elsewhere into the metropolis and the attendant demands are reflected in Comparative Literature in the last few decades in the following way: each literary tradition, tied to a dominant language group, confronts the narratives produced by this Eurocentric history, more or less. Thus we have a confrontation of Comparative Literature and East Asian languages; Comparative Literature and South Asian languages; Comparative Literature and Central/North Asian languages are just stirring. Comparative Literature and Arabic/Persian/Turkish shades off into orientalism as such ("a manner of regularized (or Orientalized) writing, vision, and study, dominated by imperatives, perspectives, and ideological biases ostensibly suited to the Orient") and, through Bulgarian, into Ottoman Studies and Balkan Studies. ${ }^{4}$ The modern period in each of these language groups relates in a different way to that main tradition, which remains "Europe" as affected by Eastern European theory filtered through France.

We are not speaking of Cultural Studies here. Very generally speaking, I think it is safe to say that Cultural/Ethnic Studies, generally considered to be the political corrective to Eurocentric Comparative Literature, legitimizes the implicit comparison by reversal. This is of course too sweeping a generalization and would have to be modified in any extended discussion.

Mainstream Comparative Literature divided over French theory. It has been touched also by the transformation of German theory through the fall of mere socialism. One consequence of these circumstances was the flight of intellectuals and the rise of comparativism. The much more resplendent social-philosophical consequence of that was Hannah Arendt and the Frankfurt School. 
This is the set we consider when we think of rethinking comparativism. When we, the first generation of U.S. PhDs in Comparative Literature, were graduate students in the sixties, we took a certain pride in asserting that the word "comparative" in our discipline was a misnomer, that the point about Comparative Literature was that it did not exactly "compare." For the last few years, some of us have been trying to rethink comparativism by pondering how exactly Comparative Literature does not compare and how that not-comparing can shelter something affirmative.

I think the solution we found in the sixties is not quite right for these times. Those of us who belonged to the U.S. mainstream of comparative literature found affinity among national literatures in place of what the verb "compare" offers: not only the etymological "pairing with" but also some hint of ranking. We found a strong ally in the theory of archetypes, psychoanalytic with C. G. Jung and R. D. Laing, literary-historical with Thomas O. Brown and Northrop Frye. Notions of the collective unconscious allowed us to bypass the problem of comparison and ranking. That line of work has found a strong champion today in my colleague and friend David Damrosch. ${ }^{5}$ I admire his work so greatly and so enjoy working with him that I should make clear that in this context, now, my thinking is different from his.

What was especially useful for us in those early days was the study of topoi, sets of imageme-narrateme-philosophemes that seemed to travel without either historical or psychic ballast across the history of literatures and cultures that make us code geography, write our world. The Greek god Apollo and the Hindu goddess of learning, Saraswati, share the swan as a familiar. Ernst Robert Curtius was our guide here. ${ }^{6}$ In the nineties, I wrote on "Echo" in this manner, finding in the nonagential voicing of the Greek mythological figure a way to think about woman's fate, particularly in postcoloniality. ${ }^{7}$ As graduate students, we had been helped by the topological phenomenologies of Gaston Bachelard, Maurice Merleau-Ponty, and Georges Poulet. ${ }^{8}$ I still recognize those trajectories in Emmanuel Levinas (though not as a placeholder for comparison) and, of course, in the work of Jacques Derrida, whose brilliant topological slides do indeed teach us to think about relations without relations between diverse European texts.

Encompassing structures and archetypo-topical texture, not strictly polarized, helped us think affinity in place of mere comparison. We know today that those great networks of affiliations work by way of exclusions. Apollo and Saraswati quietly ignore those who have no right to learning. It is perhaps not too contentious to point out also that, in today's divided world, to discover varieties of sameness is to give in too easily to the false promises of a level playing field. 
I am standing with my mother in Charles de Gaulle airport in Paris. For a week we have fed our ears on academic French. Suddenly I hear an exchange in the harsh accents of upstate New York. I turn to my mother and say, in Bengali, roughly this: "Hard to listen to this stuff." And my mother: "Dear, a mother tongue." My mother, caught up as she was in the heyday of resistance against the Raj, still extended imaginative charity to English.

I have told this story before and will say it again. Today I hold on to the fact that there is a language we learn first, mixed with the prephenomenal, which stamps the metapsychological circuits of "lingual memory." The child invents a language, beginning by bestowing signification upon a part-object (Melanie Klein). The parents "learn" this language. Because they speak a named language, the child's language gets inserted into the named language with a history before the child's birth, which will continue after its death. As the child begins to navigate this language, he/ she is beginning to access the entire interior network of the language, all its possibility of articulations, for which the best metaphor that can be found is-especially in the age of computers- "memory." By comparison, "cultural memory" is a crude concept of narrative rememorization that attempts to privatize the historical record.

Comparative Literature imagines that each language may be activated in this special way and makes an effort to produce a simulacrum through the reflexivity of language as habit. Here we translate not the content but the very moves of languaging. We can provisionally call this peculiar form of translation before translation the "comparison" in Comparative Literature.

This is not to make an opposition between the natural spontaneity of the emergence of "my languaged place" and the artificial effortfulness of learning foreign languages. Rather it is to emphasize the metapsychological and telecommunicative nature of the subject's being encountered by the languaging of place. ${ }^{10}$ If we entertain the spontaneous/artificial opposition, we will possibly value our own place over all and thus defeat the ethical comparativist impulse. Embracing another place as my creolized space may be a legitimation by reversal. We know now that the hybrid is not an issue here. If, on the other hand, we recall the helplessness before history (our own and of the languaged place) in our acquisition of our first dwelling in language, we just may sense the challenge of producing a simulacrum, always recalling that this language too, depending on the subject's history, can inscribe lingual memory-in other words, a sense of equivalence among languages, rather than a comparison of historicocivilizational content. Étienne Balibar has suggested that equivalence blurs differences, whereas equality requires them. Precisely because civil war may be the allegoric name for an extreme form of untranslatability, it is that "blurring" that Comparative Literature needs. 
I am not making claims of cultural equivalence or full translatabilitythe unexamined, dull anthropologism of cultural relativism. If you do not assume language to be isomorphic with cultural formation, you cannot move to such convictions. The apparent discrepancies in cultural power, measured on the grid of place to space, are meaningful in terms of the language's relative elaboration and importance. They become a matter of constative historical inquiry and performative resistance in the present, always waiting for what will have happened. ${ }^{11}$ This is why we must remain mindful that the assumption of equivalence is upstream from all the historical language battles of postcoloniality and neocolonial power that are still being fought and must continue to be fought. I repeat that this is not nativism, any language or language(s) can perform this function. If in situations of migration, the first language is lost, it is still a loss-not because of any kind of nationalist nostalgia-but because that originary metapsychological constitution of ethical semiosis is de-activated. I think there is some kind of historical process that shifts those mechanisms into the newly chosen "naturalized" "first" language-which operates most successfully in the second generation.

Our rethinking of comparativism starts, then, with the admission that as language, languages are equivalent, and that deep language learning must implode into a simulacrum of lingual memory. We must wait for this implosion, which we sense after the fact, or, perhaps, others sense in us, and we thus enter into a relationship with the language that is rather different from the position of a comparer, a charter of influence, who supposedly occupies a place above the linguistic traditions to be compared. In other words, I have had enough of being told that imperialism gave us the novel.

Comparative Literature, then, begins to insist on the irreducibility of idiom, even as it insists on translation as commonly understood. When we rethink comparativism, we think of translation as an active rather than a prosthetic practice. I have often said that translation is the most intimate act of reading. Thus translation comes to inhabit the new politics of comparativism as reading itself, in the broadest possible sense.

In the name of comparativism as equivalence, we are prepared to undertake a serious and continuous undoing of nationalist or national language-based reading. We have not moved too far from the regionalist impulse of the initial vision of European Comparative Literature. We have simply announced a worldly future. It is our hope that, in this process, the performativity of comparativism will face the task of undoing historical injustice toward languages associated with peoples who were not successfully competitive within capitalism - with the added proviso that these languages attempt to establish an interconnection among themselves through our disciplinary and institutional help. This will take 
us a step outside the necessarily nation-centered and culture-centered frontiers of the United Nations.

The idea of a subaltern collectivity of languages and literatures outside of national-language restrictions is a difficult one. In order to take the diversified subaltern or less-taught languages out of enclavist or collectivist pedagogy and politics, to save Comparative Literature from unacknowledged and exclusivist comparison, structural and epistemological changes are required. I will quote some prose here that reflects a long, ongoing effort at institutional change. The implicit terms of resistance-this is against globalization-entrenches comparison beyond the discipline, indeed situates the discipline upon contemporary cognitive topography in a negligible niche. I leave this caution here, proceed to the institutional passages, and close with two readings that can only look forward to the necessary yet impossible institutional guarantee of access to equivalence. Here is the institutional passage, used in a couple of grant proposals:

Even as we want to include Europe and necessarily the United States in any version of a globalized world, we also recognize that our efforts cannot succeed without a thorough-going program of the less-taught languages of that world ... This latter group could only be taught for a few semesters, with insufficient quality control, by insufficiently trained instructors, and with no possibility of students moving on to a major or a doctoral track. This lack of parity between established and less-taught languages goes against the very spirit of an enlightened globalization of the curriculum. This is matched by the lack of parity between teachers of language and teachers of literature in all U.S. universities .... The labor is, of course, immense. It will involve faculty development seminars, postdoctoral fellows, extensive and new recruitment procedures, and the involvement of national professional associations. There must be a consortium, since the less commonly taught languages are many, the need is acute, no single university could hope to cover all bases and, given distant learning resources, the first stages of language learning could easily be shared. ${ }^{12}$

It is in view of the resistance to institutional change that I often speak of the humanities supplementing globalization by providing a world. The worldliness of our new Comparative Literature could be a key element in this continuing and persistent effort. For, given the differential between the "first" language and others, the equivalence that would formalize our new Comparative Literature will never be fully established. We must always work in the element of simulacra, putting in place a bond between the world's neglected languages. The literature of Okinawa will then take its place with the wisdom songs of Ghana and the historical fables of the Popol Vuh.

I want to make a methodological point before I conclude. We start from an assumption of linguistic equivalence, which rests on language's 
capacity to inscribe. Always with one language as accidental standard, we escape national restrictions and create the simulacrum of equivalence through deep language learning across the spectrum of the subaltern languages of the world. The diversity and singularity of idiom remain a constant reminder of the singularity of languages. The absence of material equivalence provokes historical study. Within this procedural frame, how do we read now as comparativists?

Over the last few years, teaching the introductory course in Comparative Literature and Society to graduate and undergraduate alike, I have drawn a conclusion: in disciplinary method we remain astute. Attention to idiom, demonstration through textual analysis, acquisition of expertise in plotting the play of logic in rhetoric and vice versa. In so far as our object of investigation is concerned, however, we acknowledge as comparativist any attempt that the text makes to go outside of its space-time enclosure, the history and geography by which the text is determined. Thus disciplinary convention expands toward what would otherwise escape it, and the field expands greatly, in many ways.

I now test my notion of textual comparativism with a look at Medoruma Shun's short story translated "Hope."13

"Hope" has been called "the first post-colonial work of Okinawan literature."14 Like all postcoloniality, it looks forward to an undecidable future. Its very title, "Hope," out of joint with the narrative content, gives us a sense of this. How can it help us in the task of rethinking Comparative Literature in view of such an undecidable future?

By my disciplinary responsibility I would have to undertake the difficult journey of entering Japanese idiom and its relationship to the idiom of Okinawa. I would have to plot the relationships as I would, with appropriate differences, in Ireland or Hong Kong. I am ill prepared for this. What I can attempt now is the lesson of reading-locating an impulse toward comparativism in this new sense in the story itself.

The story is about a sacrifice and a suicide. Upon a scene of political conflict, such a double gesture often reflects a comparativism of last resort: a plea to the political other to recognize equivalence, to respond, and, finally, to end oppression. I have been long attracted to this species of comparativism, attempting to go outside of the space-timc enclosure, when that enclosure means oppression, colonial or gendered or both, undoing history and geography by inscribing the body with death.

I place the story of "Hope" in that genre with "Can the Subaltern Speak?" with suicide bombing in Palestine, with Viken Berberian's The Bicyclist, with Santosh Sivan's "The Terrorist," a film dealing with anticolonial resistance and gender in Sri Lanka.

One of the characteristics of this species of comparativism in extremis is the double bind between ethics and politics. This too is a theme that attracts me greatly. 
(Comparativism in extremis is not a disciplinary choice of method. It can be located in our objects of investigation if it is represented. Comparativism in extremis is a political gesture when response [perhaps based on that lesson of equivalence in a context broader than our discipline] is denied. I have given above a few examples of such representation, including "Hope." Bamako, a film I will discuss at the end of this essay, is a teaching text, not a representation of comparativisim in extremis. The film hopes that its lesson-the difference between resistance and the people-will be learned. Other examples of the representation of comparison in extremis-merely indexed-is a line in Rabindranath Tagore that I have discussed elsewhere. Speaking of the people to whom human rights were denied millennially in India, he writes: " mrityumajhe hobe tobe chitabhashshe shobar shoman'-you [addressing his "unfortunate country"] will then be equal to all of them in the ashes of death, thus predicting the death of a nation." The only thing that will make me equal to you, because you deny response, is a shared death. This is also the theme of Ernesto Cardenal's poem "Prayer for Marilyn Monroe" (1965), made into a film by the Instituto Cubano de Arte e Industria Cinematográfico [ICAIC], where the items of comparison are Marilyn Monroe, with her desperate life on the one hand and the millions of dead children in Latin America on the other, standing in as victims of the U.S. system, a place of no response. Cardenal is a priest, a liberation theologian-for him in death the two sides were equal in God's eyes, comparison as equivalence in extremis. Perhaps it may be said that our lesson of learning equivalence, practicing equivalence, indexing a small epistemic change or shift, may come to facilitate a world where comparison in extremis will no longer be required.)

A double bind, then. Between ethics (I must not kill) and politics (I can have a "response" from my nonrespondent[s] only in a shared death).

To some the double bind seems a dangerous idea. And yet, to deny its pervasiveness leads to failed revolutions. Paradoxically, to acknowledge its pervasiveness does not lead to unqualified success. This is its danger. I have put together a somewhat positive description, which I will share with you today. This by no means exhausts the power and danger of the double bind. The one thing that we can propose is that the fiction and reality of comparativism in extremis often makes visible the double bind between ethics and politics.

Here, then, is my somewhat bland and optimistic account of the double bind, which some of you have already heard:

The double bind can be a general description of all doing, all thinking as doing, all self-conscious living. Contradictory instructions come to us at all times. We learn to listen to them and remain in the game. 
When and as we make a decision, we know that we have broken the double bind into a single bind, as it were, and that change will have to be undertaken soon, or, things will change. If we don't know this, our self-congratulation is typically followed by denial or bewilderment. ${ }^{15}$

To put it formulaically, as does the fiction, the political situation requires the violence of sacrifice: "What Okinawa needs now is not demonstrations by thousands of people or rallies by tens of thousands, but the death of one American child." 16 Yet the ethical unacceptability of violence requires the destruction of the political subject or actor. The pull of the ethical is so strong that the political act cannot be described as willed: "Just as fluids in the bodies of a small creature that is frightened suddenly turn into poison, [so] this deed of mine is natural and what had to happen [hitsuzen] for this island, I thought." And the pull of the political is so strong that the act representing the ethical is also a sacrifice and a destruction. The impossibility of containing the ethical subject in its worldly envelope is indicated in the text by the management of time:

At the moment that I reclosed the trunk, the sun broke through the cloud veil that covered the sky. I am sweating, and I break out in goose bumps. I crossed the forest on foot ... and returned home. . . . The air conditioning doesn't work . . . I lower the windows but I pour with sweat. I went up to Naha city . . . . I pour a bottle of gasoline on my jacket and pants. ... A group of junior high schoolchildren came running . . . ${ }^{17}$

The sweating and sacrificing body breaks through into the present tense as the narrative progresses in the past tense. The body reenters the narrated past as an object before language in the last sentence.

On the side of the dominant, there is the longing for a release from the double bind between nationalism (the political) and responsibility (the ethical). Thus Oe Kenzaburo repeats a phrase in 1969: "Is it possible to change to a Japanese who is not a Japanese?"18

The dominant can also refuse this longing and simply deny the double bind. Here is a comment from the staff of the Japan Policy Research Institute: "Americans are likely to be shocked by Medoruma's subject matter and tone." It is a well-meaning comment, for the staff then proceed to list U.S. marine criminal activity against Ryukyuans, especially females. Yet to separate nationalism and responsibility is precisely a denial of the double bind that can reduce resistance to the politically correct.

One of the incidental but altogether astute moments in "Hope" is when the narrator recognizes that every inhabitant of the island is not infected by what I am calling comparativism in extremis-the necessity to call for a response from the colonizer. The first gesture from an islander is the innocent one of joy at seeing a known person on TV! And the last gesture is the equally innocent frivolity of the children kicking 
the agent reduced to object. Between these two gestures of innocence lies the story, apparently useless. Commemorated in fiction, it becomes useful if we learn how to read as we mark time toward a comparativism of equivalence.

Without this, we cannot pick up the message if an artist points at the distance between protest and the people. Abderrahmane Sissako's film Bamako (2006), for example, is regularly read like a documentary of protest by most policy-oriented folks.

The film stages a trial, held in an African compound, by African judges and lawyers, with the participation of two white lawyers on either side, of the World Bank for its crimes in Africa. The trial is contained within fragments of local action and a slim subplot about the death of a charismatic singer's husband.

The new comparativism can read this film as a filmic discourse on epistemic discontinuity in the welding of place. We notice how much of the staging is in terms of a relief map of languages, colonial and local. The trial is framed by a community where only the ones who have graduated into the discursive practice of the good whites are able to "speak the truth." The director took good care to point this out by making the subplot with a very attractive singer, by closing the film with her, focusing on her husband's death, and making clear that it has little to do with the main argument. The high point of eloquence in the film, and deliberately, if you notice the framing, is the good white guy (apparently the director just gave them the parts and said, "now speak")-makes us think precisely about the problem. There are also the moments of grassroots choice when access to the "trial" of the World Bank is turned off by the young men of the village, the real agents of collaboration with the destruction of the country. The bridge agents are a woman who is accused of not fitting the evidentiary structure and, on another level altogether, the traditional healer who utters (apparently in a language not necessarily understood by the "native speakers"). The complexity of the framing is evident also in the presence of the film within the film, an exaggerated eye-catching African Western.

The entire film can be a figuration of why resistance against the transnational agencies misfires. But it is inconvenient and counterintuitive to understand this.

A few images now merely to suggest how the film might figure the separation, indeed the discontinuity, between resistance and the people. ${ }^{19}$ It is not without significance, surely, that the World Social Forum had had a meeting in Bamako just before the film's release. I will repeat my earlier points in order to relate them to the images.

We are looking at a symbolic trial of the World Bank, staged in an African compound in Bamako. Sissako places two persons outside the frame: 
the charismatic female singer who would travel easily into the musical circle of global protest and the traditional healer. The name of the film appears on the screen after those two placings outside of the work.

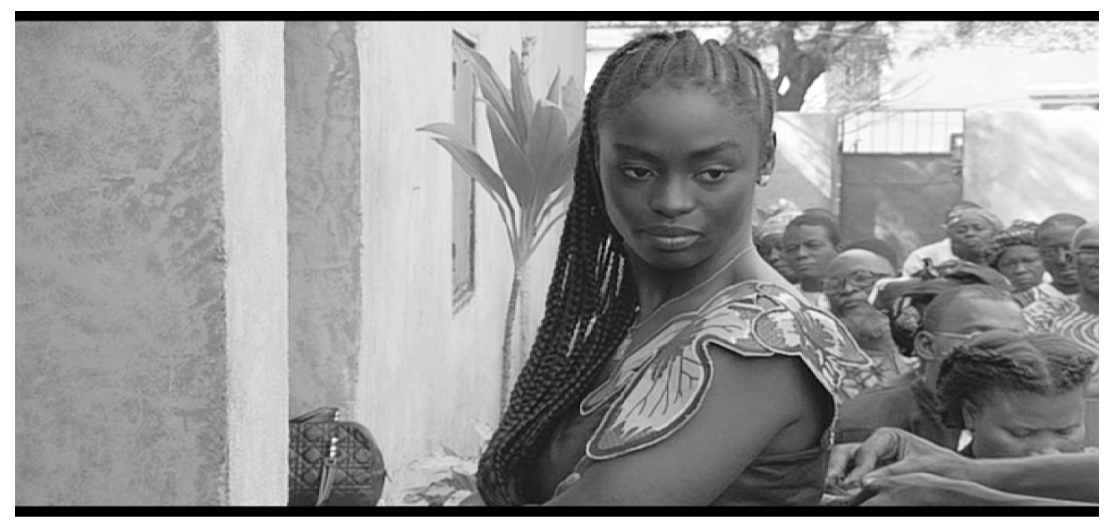

Figure 1. Singer interrupts film to have bustier laced

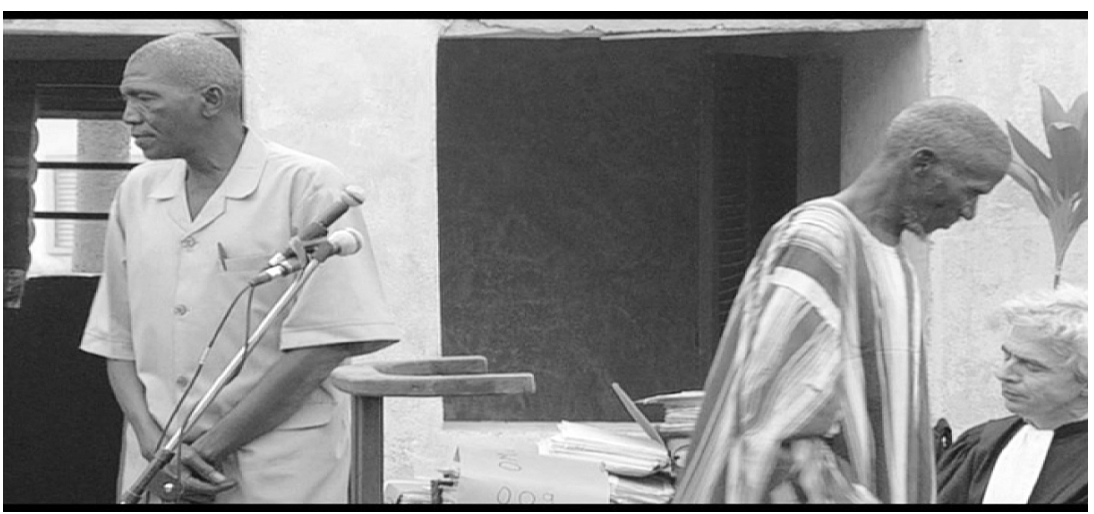

Figure 2. Healer leaves trial

Here is the woman singing simply to show her forceful presence in the film. Indeed this bit is used to promote the film-although it is not part of the trial, where the participating Africans have achieved sufficient continuity with the European Enlightenment to be able to criticize its travesty: 


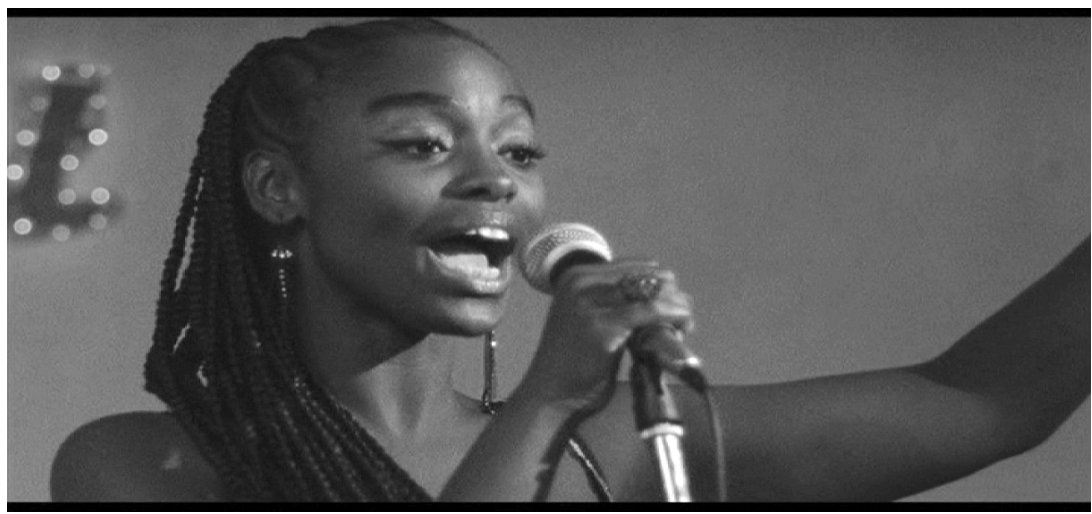

Figure 3. Singer's dynamism

Now to images where, in the film, Sissako distinguishes carefully between the difference in the response.

First, the good white guy testifying against the World Bank. He speaks in metaphors and the audience is shown responding collectively.

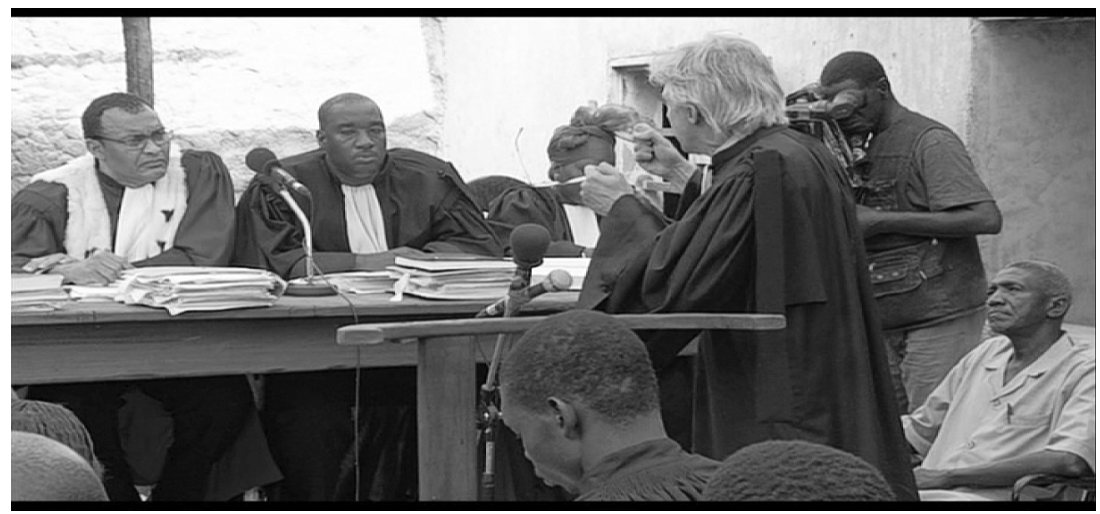

Figure 4. Good white guy

Next, the black woman testifying. She is eloquent, speaks more statistics. The response is more singular, less public. 


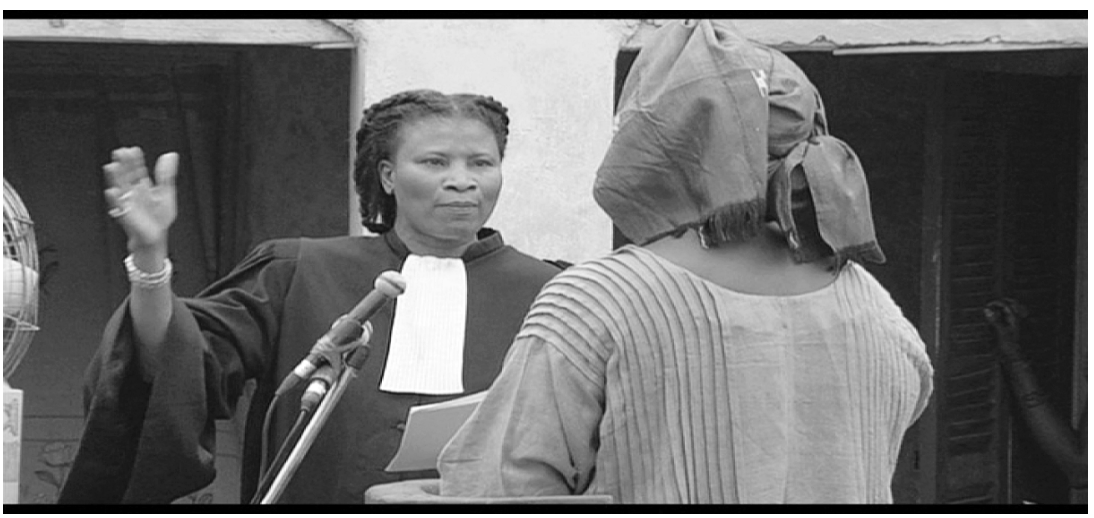

Figure 5. Black woman testifying

Then the traditional healer, who finally intervenes, out of place. This is an undecidable moment, the moment of a double bind. For, if Mamadou Diouf is right, the Africans here do not necessarily understand what he sings. It may indeed be a procedural complaint on his own behalf. The response is mysterious, a pattern of close-ups of individual faces. We contemplate the distinction between singularity-repeatable difference-and the individual subject.

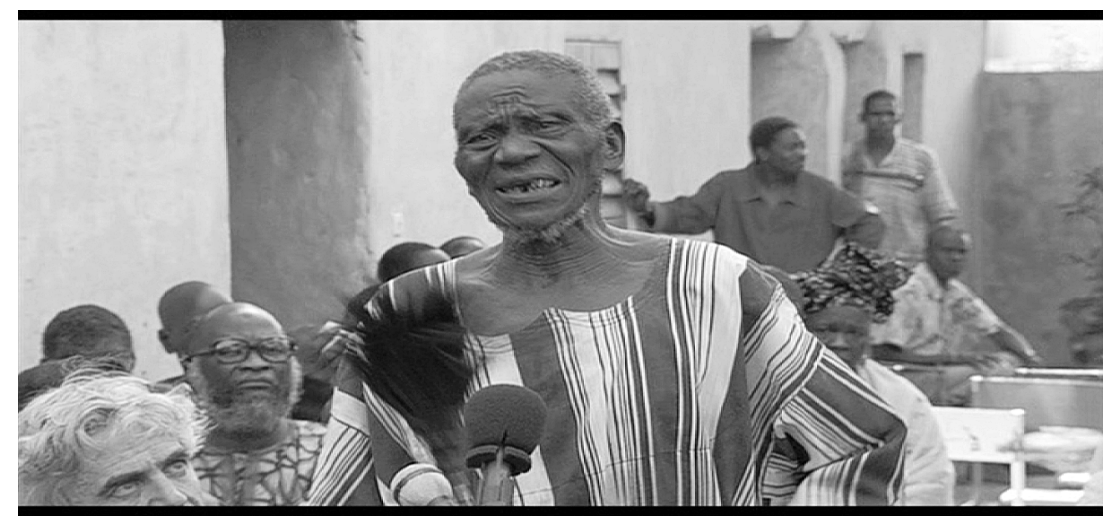

Figure 6. Healer singing

Contrast the much more innocent and open response to the AfricanWestern film within a film. This too is discontinuous from the trial. The African Western, with Danny Glover starring, is a generic opposite from Bamako, the film in which it is embedded. That is already a discontinuity. Further, the kind of innocent joy in such bloody mayhem that is portrayed 
in the mother and daughter is remote indeed from a critique of Western benevolence, from a social position in society within that enclosure, as represented by the "educated" Africans participating in the trial.

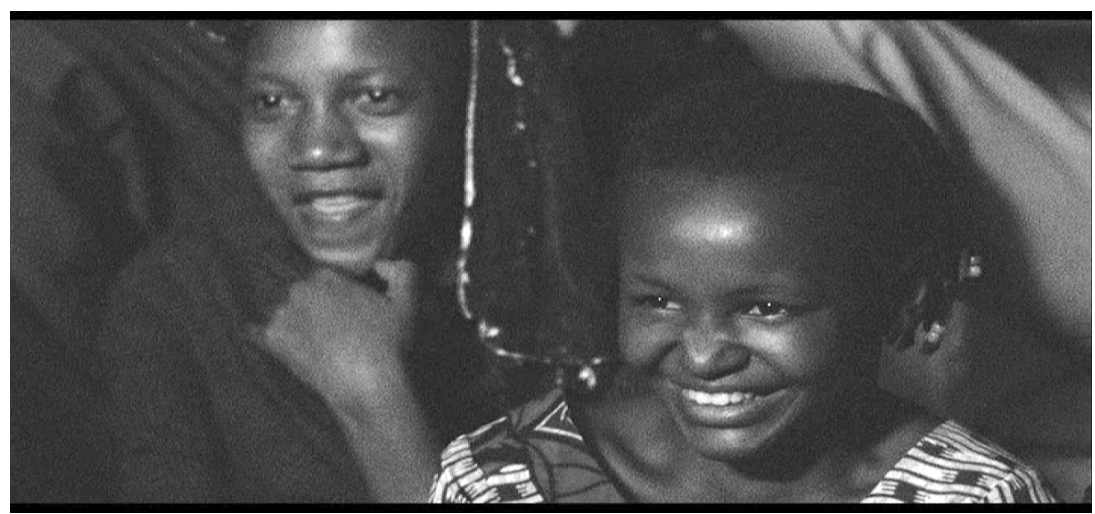

Figure 7. Innocent response to African Western

Without overparsing, it remains noticeable that there are no white women in the film, no global feminist solidarity as is evident at the World Social Forum. Gender is the alibi for the entire spectrum of good and bad globalizing intervention. Has a criticism been represented here on the workings of the screen? For, as I have mentioned, Sissako takes good care to present a taxonomy of black women, roughly in terms of distance from the European Enlightenment, if you like. Islam is elsewhere. The "Muslim" woman (presumably the other African women are Muslim too) swears in the home of Allah and disappears from the film. And, at the film's end, an Islamic ritual-the funeral of the man who begins the film-with no more than minimal subtextual development. And yet the implicit possibility of a male solidarity is clearly shown across the color-class line across the line where the black African has achieved rational epistemic continuity with the white European. When Maitre Rapaport-incidentally an actual person-interrupts on the side of the prosecution, his white colleague says to him, not waiting for procedure: "Shut up," with a gesture behind his rump. 


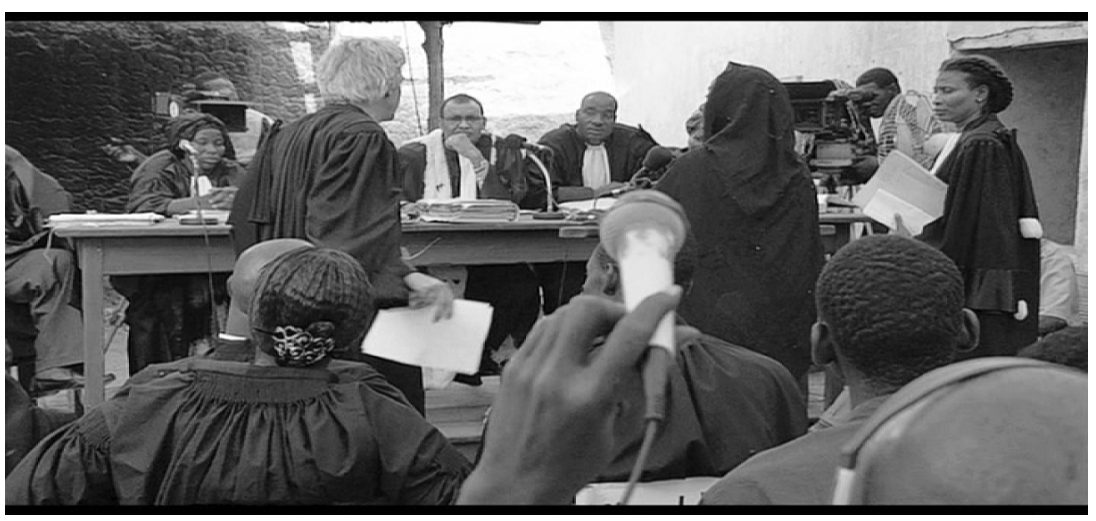

Figure 8. "Shut up"

When he addresses the court, the men active in the village world of unofficial microgovernance (please contrast this to world governance), disconnect the loudspeaker, also without waiting for procedure.

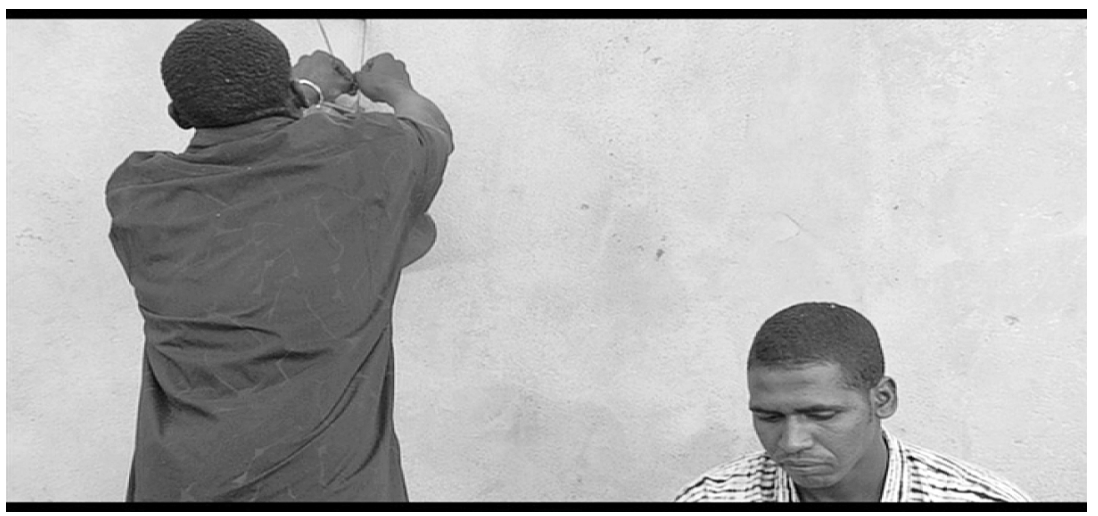

Figure 9. Africans disconnect loudspeaker

Sessako and I have slipped in the question of gender, bigger than capital, since both sides are caught in reproductive heteronormativity and use gender as an instrument, an alibi- "the surrogate proletariat"; a question that the organized left intellectual, out of touch, expects only women and queers to ask, which is why a feisty philosopher like Agnes Heller, deeply sympathetic to women, says she is "against 'feminism'."

In conclusion, I quote two paragraphs from my forthcoming book to designate the position from where my stereotype of myself rethinks comparativism. 
In 1992, asked to give the first T. B. Davie Memorial lecture at the University of Cape Town after the lifting of apartheid, I suggested that we learn to use the European Enlightenment from below. I used the expression "ab-use," because the Latin prefix "ab" says much more than "below." Indicating both "motion away" and "agency, point of origin," "supporting," as well as "the duties of slaves," it nicely captures the double bind of the postcolonial and the metropolitan migrant regarding the Enlightenment. As such, we want the public sphere gains and private sphere constraints of the Enlightenment; yet we must also find something relating to "our own history" to counteract the fact that the Enlightenment came, to colonizer and colonized alike, through colonialism, to support a destructive "free trade." But "ab-use" can be a misleading neographism and come to mean simply "abuse." That should be so far from our intentions that I thought to sacrifice precision and range and simply say "from below." This too rankles, for it assumes that "we," whoever we are, are below the level of the Enlightenment. A double bind.

The phrase "double bind" comes from Gregory Bateson's Steps to an Ecology of the Mind, first published in 1972. To begin with, the double bind was a way for him to understand childhood schizophrenia qualitatively. Bateson was, however, aware that "[b] oth those whose life is enriched by trans-contextual gifts and those who are impoverished by trans-contextual confusion are alike in one respect: for them there is always or often a 'double take.' In other words, inhabiting thus the two ends of the spectrum, the double bind could be generalized. In "A Theory of Play and Fantasy," Bateson spelled out the training of the imagination in terms of a mise en abyme, an indefinite series of mutual reflections. This "training," the bulwark of an aesthetic education, habitually fails with religion and nationalism: "Up in the dim region where art, magic, and religion meet and overlap, human beings have evolved the 'metaphor that is meant,' the flag which men will die to save, and the sacrament that is felt to be more than 'an outward and visible sign, given unto us'"; it is interesting that Freud mentions the same two items- "Throne and Altar"-in "Fetishism," as the monitors of fetishistic illogic.

A comparativism rethought might restore the metaphor to this white mythology. In Goethe's spirit, we can interminably prepare ourselves to work in the hope of a promise of equivalence to subaltern spaces and times, a hope cradled in despair except when reading flourishes.

Working a century ago, Franz Boas clearly indicated the need for deciding if the cultures of "primitive" places had independent origins or were influenced by transmission. To compare seemed to be the only solution. The time for that initial anthropologistic comparativism is long over for us. Undoubtedly we should not rule out the contrast between historically independent origin and a comparativist study of dissemina- 
tion from our discipline. In order to be able to do this as part of the discipline, however, we have to take a step back and perform the epistemological difference, looking forward to an epistemic difference "to come": the lesson of thinking the equivalence of language, potentially, in the metapsychological theater.

\section{Columbia University}

\section{NOTES}

1 Pascale Casanova, The World Republic of Letters, trans. M. B. DeBevoise (Cambridge, MA: Harvard Univ. Press, 2004).

2 René Etiemble, The Crisis in Comparative Literature, trans. Herbert Weisinger and Georges Joyaux (East Lansing: Univ. of Michigan Press, 1966). Originally published as Comparaison n'est pas raison (Paris: Gallimard, 1963).

3 Charles Bernheimer, ed., Comparative Literature in the Age of Multiculturalism (Baltimore: Johns Hopkins Univ. Press, 1995), 44.

4 Edward W. Said, Orientalism (New York: Vintage Books, 1995, c1978), 202.

5 David Damrosch, What Is World Literature? (Princeton, NJ: Princeton Univ. Press, 2003).

6 Ernst Robert Curtius, European Literature and the Latin Middle Ages, trans. Willard R. Trask (New York: Harper and Row, 1963, c1953).

7 Spivak, "Echo," New Literary History 24, no. 1 (1993): 17-43.

8 For a checklist, one might think of Gaston Bachelard, The Psychoanalysis of Fire, trans. Alan C. M. Ross (Boston: Beacon Press, 1964); Water and Dreams: An Essay on the Imagination of Matter, trans. Edith R. Farrell (Dallas, TX: Dallas Institute Publications, 1983); Poetics of Space, trans. Maria Jolas (Boston: Beacon Press, 1958); Maurice Merleau-Ponty, Phenomenology of Perception, trans. Colin Smith (London: Routledge \& Kegan Paul, 1962); The Visible and the Invisible, trans. Alphonso Lingis (Evanston, IL: Northwestern Univ. Press, 1968); Georges Poulet, Studies in Human Time, trans. Elliott Coleman (Baltimore: Johns Hopkins Univ. Press, 1956), The Interior Distance, trans. Elliott Coleman (Baltimore: Johns Hopkins Univ. Press, 1959); The Metamorphoses of the Circle, trans. Carley Dawson (Baltimore: Johns Hopkins Univ. Press, 1966).

9 Alton Becker, Beyond Translation: Essays Toward A Modern Philology (Ann Arbor: Univ. of Michigan Press, 1995), 12.

10 " $[\mathrm{I}]$ it would be bad natural history to expect the mental processes and communicative habits of mammals to conform to the logician's ideal." Gregory Bateson, Steps to an Ecology of Mind (Chicago: Univ. of Chicago Press, 2000), 180.

11 For the structure of constative-performative-attendance, see Jacques Derrida, Rogues: Two Essays on Reason, trans. Michael Naas and Pascale-Anne Brault (Stanford, CA: Stanford Univ. Press, 2005).

12 In the hope of increasing institutional attention, I have included these words also in "Translation in the Undergraduate Curriculum," forthcoming in the ADFL Bulletin, and will probably continue to re-cite them indefinitely.

13 For an expert account of the story, see Ikuo Shinjo, "Homoerotikusu no seijiteki haichi to 'reisen': Okinawaeno/ kara no manazashi no koso," Frontiers of Gender Studies (F-GENS) Annual Report Number 5 (2005), Ochanomizu University. Presented as "The Political Formation of the Homoerotics and the Cold War: Battle of the Gazes at and from Okinawa," at the American Comparative Literature Association Annual Conference at Princeton University, March 23-26, 2006. 
14 Quoted in Japan Policy Research Institute (JPRI) Critique 6, no. 12 (1999), www.jpri.org/ public/crit6.12.html.

15 The pervasive presence of the acknowledgement of the double bind in Derrida's work can allow us to think of deconstruction as a philosophy of (praxis as) the double bind. In Gilles Deleuze and Félix Guattari's Anti-Oedipus, trans. Robert Hurley et al. (Minneapolis: Univ. of Minnesota Press, 1992), the attempt to think schizophrenia in a more general sense leads to the French title (subtitle in the English): "Capitalism and Schizophrenia." 16 Shun Medoruma, "An Okinawan Short Story," trans. Steve Rabson, JPRI Critique 6, no. 12 (1999), www.jpri.org/public/crit6.12.html. All quotes are from this translation. Translation often modified.

17 I have emphasized the tensed words to show the play of present and past tenses.

18 Oe Kenzaburo, Okinawa Notes (Tokyo: Iwanami Shoten, 1970), 16. I am grateful to Shinjou Ikuo for making this text available to me. I thank Norie Oka for producing a digest at short notice.

19 All images from the film Bamako (2006) by Abderrahmane Sissako @ Archipel 33 are reproduced by permission.

20 Bateson, Steps to an Ecology of Mind, 272.

21 Bateson, Steps to an Ecology of Mind, 183.

22 Sigmund Freud, "Fetishism," Standard Edition of the Complete Psychological Works of Sigmund Freud, trans. James Strachey (New York: Norton, 1961, c1930), 21:152. 